\title{
Arabidopsis Transcription Factors and the Regulation of Flowering Time: A Genomic Perspective
}

\author{
Oliver J. Ratcliffe and José Luis Riechmann* \\ Mendel Biotechnology, 21375 Cabot Blvd., Hayward, CA \\ 94545, USA
}

\begin{abstract}
The availability of the Arabidopsis genome sequence allows for novel approaches in the analysis of many aspects of plant biology. Approximately $6 \%$ of Arabidopsis genes code for transcription factors, which can be grouped into different families according to similarities within the DNA binding domains. Transcription factors are critical regulatory components of the pathways that underpin many aspects of plant growth, development, and physiology. In particular, a substantial number of them are emerging as having crucial roles in controlling one of the most important, but complex, steps in the plant life cycle: the transition to flowering. Genome-wide studies offer the opportunity to gain a comprehensive understanding of this polygenic process, making it possible to appreciate both the large number of genes involved, as well as the complex regulatory networks into which those genes are integrated.
\end{abstract}

\section{Introduction}

The availability of the first plant genome sequence, that of Arabidopsis thaliana, (Lin et al., 1999; Mayer et al., 1999; Arabidopsis Genome Initiative, 2000; Salanoubat et al., 2000; Tabata et al., 2000; Theologis et al., 2000), allows for global, or genomic, analyses on many aspect of plant biology that, until recently, have been studied only through more traditional approaches. This shift from a 'gene-centric' to a 'genome-centric' perspective in eukaryotic biology is especially appropriate for the study of transcriptional regulation, and of transcription factors in particular (reviewed in: Riechmann and Ratcliffe, 2000; Riechmann, 2002). Transcription factors are the most numerous of the different types of proteins involved in transcription. They are the main (although not the only) protein components of the combinatorial logic of transcription, and the principal factors upon which mechanisms for selectivity of gene activation are built.

To gain a genomic appreciation of biological processes, it is necessary to compile complete lists of participating elements. A first step in this direction is the comprehensive analysis of the genome of interest through sequence

*For correspondence. Email jriechmann@mendelbio.com; Tel. (510) 259-6151; Fax. (510) 264-0254. comparisons. Transcription factor genes comprise a substantial fraction of any eukaryotic genome, and the majority can be grouped into a handful of different, often large, gene families according to the type of DNA-binding domain they encode. Within these families of related genes, functional redundancy or overlap is not unusual, and therefore the proper characterization of particular genes might require their study in the context of their closest relatives. The Arabidopsis complement of transcription factors has been the subject of an extensive genome-wide descriptive analysis, which also included a comparison with those of Drosophila melanogaster, Caenorhabditis elegans, and Saccharomyces cerevisiae (Riechmann et al., 2000). It was determined that the Arabidopsis genome codes for more than 1,500 transcription factors, or approximately $6 \%$ of its total number of genes. Less than $10 \%$ of these factors have been genetically and functionally characterized, usually through traditional genetic approaches whereby genes are first defined by a mutant phenotype and then isolated. For the majority of these transcriptional regulators, functional characterization is limited to the description of phenotypic differences between mutant and wild-type plants, and determination of their expression patterns. However, there is still very little knowledge of their modes of action; that is, of the genes that they regulate and of the mechanisms that they use to achieve that regulation. Thus, the function of the Arabidopsis complement of transcription factors, considered as a whole, and the dynamic relationship between the genome, the transcriptional regulators, and the transcriptome, remain largely unexplored (Riechmann, 2002).

Differential gene expression is a key element of developmental processes in multicellular eukaryotes, and thus transcription factors are often the master regulatory genes that direct the development of such organisms. In plants, the decision to flower is a critical developmental step in the life cycle, and a complex web of control pathways has evolved to ensure that this occurs at the most appropriate time. Studies in Arabidopsis have shown that more than 80 genetic loci are involved the regulation of the floral transition in response to a range of internal and external variables. Such variables or factors include daylength (photoperiod), prolonged cold periods (vernalization), the developmental state of the plant, and the action of hormones, such as gibberellins (Koornneef et al., 1991; Martínez-Zapater et al., 1994; Levy and Dean, 1998a, b; Simpson et al., 1999). Thus, the control of flowering time is under extreme polygenic control. Increasing numbers of genes that affect flowering time in Arabidopsis are being cloned, and many of them encode transcription factors (Table 1).

In this article, we first provide a succinct overview of the transcription factor gene complement of the Arabidopsis genome, and we particularly consider it in terms of biological complexity and developmental processes in 





plants. We then summarize the current understanding of flowering time in Arabidopsis, with an emphasis on transcriptional regulation (more comprehensive and general reviews on the control of the reproductive switch in plants have been published elsewhere: Koornneef et al., 1998; Levy and Dean, 1998b; Simpson et al., 1999; Reeves and Coupland, 2000). In the last section, we revisit and combine both topics in an attempt to provide a genomic view of the flowering time gene regulatory network, and of future research in the field.

\section{The Arabidopsis Transcription Factor Gene Complement}

The Arabidopsis genome ( $125 \mathrm{Mbp}$ of DNA) contains approximately 26,000 genes (Arabidopsis Genome Initiative, 2000). The corresponding complement of transcription factor coding genes has been described and reviewed in detail elsewhere (Riechmann et al., 2000; Riechmann, 2002), and only the most salient features are listed here.

- The Arabidopsis genome codes for at least 1,572 transcription factors (or $\sim 6 \%$ of its total number of genes), which can be grouped into more than 45 different gene families. Such a content of transcriptional regulators is comparable to those of other eukaryotic organisms: transcriptional regulators represent approximately $3.5,3.5$, and $4.6 \%$ of the genes in yeast, $C$. elegans, and Drosophila, respectively, and $4.6-6.6 \%$ in humans.

- Many of the Arabidopsis families of transcription factors are large, with close to 100 members. The three largest families, AP2/ERF (APETALA2/ethylene response factor; this family was initially referred to as AP2/EREBP, for AP2/ethylene responsive element binding protein), bHLH (basic-region helix-loop-helix), and MYB-(R1)R2R3, each represent $\sim 9 \%$ of the transcription factor gene complement.

- Approximately $45 \%$ of the Arabidopsis transcription factors belong to gene families that are specific to plants, and $\sim 53 \%$ belong to families that are found in the three eukaryotic kingdoms of plants, animals, and fungi.

- Diversity in transcription factors among different organisms is large. In addition to differences in the composition of the transcription factor gene complement, the Arabidopsis factors that belong to families that are common to all eukaryotes do not share significant similarity with those from the other kingdoms, except in the conserved DNA binding domains that define the respective families. Furthermore, diversity in protein sequence and structure is increased by domain shuffling. Shuffling of some of the DNA-binding domains that are present in all eukaryotes has generated novel transcription factors with plant-specific combinations of modules.

- Arabidopsis transcription factor genes have followed duplication and rearrangement patterns that are similar to those of the genome as a whole. The genome contains many duplications, including small tandem duplications as well as large-scale duplications localized on different chromosomes (Arabidopsis Genome Initiative, 2000; Vision et al., 2000). Approximately $45 \%$ of the total number of transcription factors comprise pairs or groups of highly related sequences. These duplications are more frequently found in different chromosomes, than in tandem repeats.

In summary, analysis of the Arabidopsis genome revealed a substantial number of transcription factor genes, most of which have not been functionally characterized, and illustrated the large degree of diversity in transcriptional regulators that is present among the different eukaryotic kingdoms (Riechmann et al., 2000; Riechmann, 2002).

\section{Transcription and Biological Complexity}

Evolution of life on earth has progressed through a trend of increases in size, diversity, and complexity (Carroll, 2001). Biological complexity is a term for which the abstract or intuitive meaning is apparent, but which eludes precise definition. Despite this, however, there have been several proposed metrics and attempts to quantify biological complexity, by considering, for example, the number of different physical parts in an organism, such as cell types or genes (reviewed in Carroll, 2001). Determination of the genome sequence of different eukaryotes, however, has revealed that the association between gene number and complexity is not immediate: Drosophila melanogaster contains $\sim 13,000$ genes, whereas the arguably simpler nematode Caenorhabditis elegans has $\sim 19,000$, and 26,000 genes were identified in the genome of Arabidopsis (The C. elegans Sequencing Consortium, 1998; Adams et al., 2000; Arabidopsis Genome Initiative, 2000). More surprisingly, a mere $\sim 30,000$ genes were predicted from the human genome sequence (International Human Genome Sequencing Consortium, 2001; Venter et al., 2001), although there is uncertainty about this estimate (see, for example: Hogenesch et al., 2001; Wright et al., 2001). Alternative splicing, which is frequently observed for human genes, might be an important contributor to complexity, substantially increasing the number of different proteins that are derived from the genome. Nevertheless, since absolute numbers of genes or parts seem inadequate as a measure of biological complexity, other parameters have been used (reviewed in Carroll, 2001). Among such parameters is the number of interactions among parts. In particular, it has been proposed that biological complexity might be better explained by considering networks of transcription factors and the genes they regulate (connectivity of gene-regulation networks, Szathmáry et al., 2001), or the number of theoretical transcriptome states that a genome could achieve (Claverie, 2001). This reasoning was based in part on the observation that there is a trend to increase the number of transcription factors from yeast, to $C$. elegans, to Drosophila, and to humans (Szathmáry et al., 2001) (although the assertion that for all transcription factor families their members increase in 


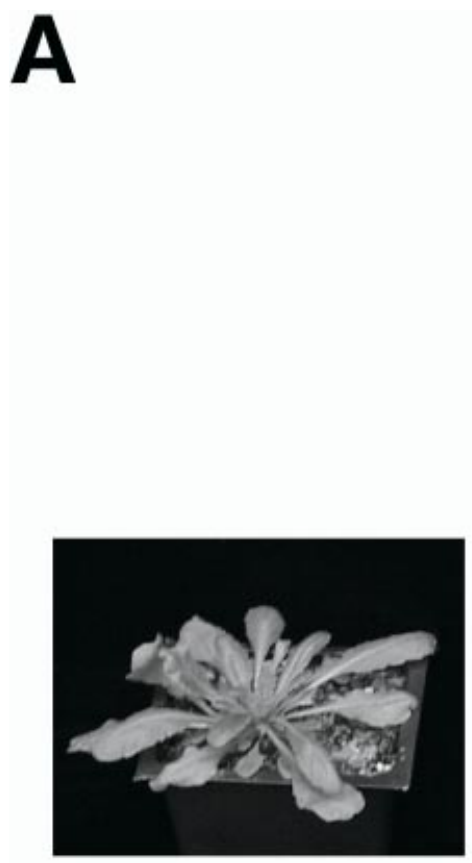

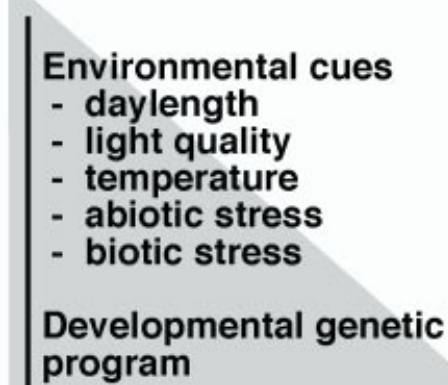

$$
\text { program }
$$

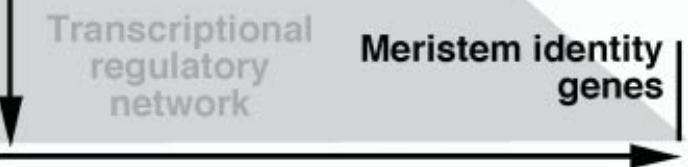

FLORAL TRANSITION
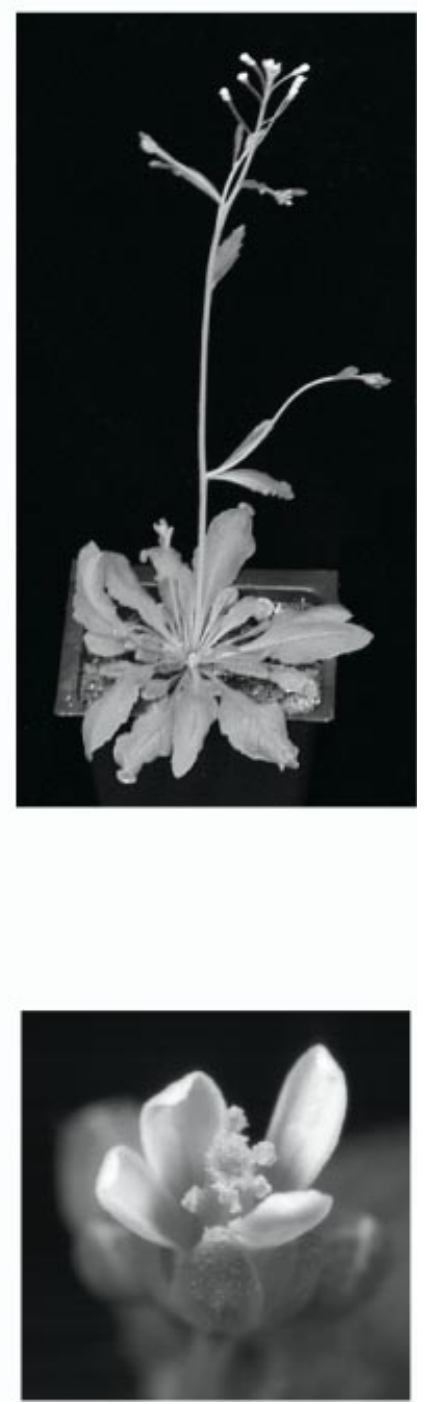

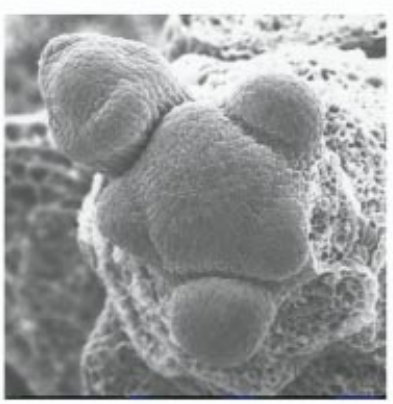

FLOWER DEVELOPMENT

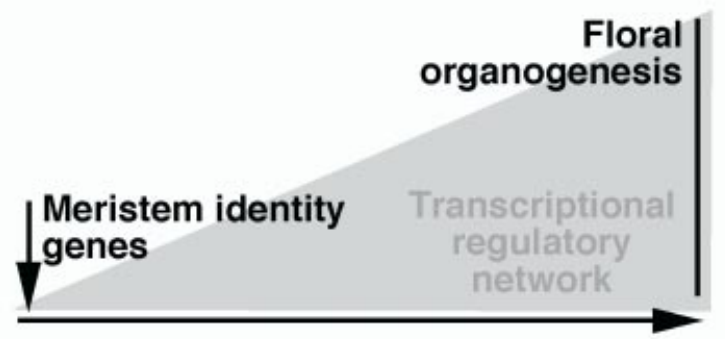

Figure 1. Transcription in plant developmental processes. (A) The floral transition, a plastic process. The reproductive switch is under the control of multiple different inputs, including the plant's intrinsic developmental program as well as many different environmental cues. A complex web of pathways responds to these inputs and controls the transition. Transcriptional regulation plays a prominent role in this network, and the inputs are eventually resolved into the upregulation of master meristem identity genes. (B) Flower development. This process is initiated by upregulation of master meristem identity genes, and is relatively inflexible, being achieved via the same sets of genes irrespective of the prevailing conditions.

number in such order, is not correct, since different gene families have been amplified to a different extent in each organism, see: Riechmann et al., 2000; Riechmann, 2002).

Following such reasoning, why do plants, as represented by Arabidopsis, have a complement of transcription factors that is more complex than that of Drosophila and $C$. elegans, and perhaps even similar in that respect to that of humans (Riechmann, 2002)? This 'peculiarity' has been interpreted in the context of the complexity of secondary metabolism in plants (Szathmáry et al., 2001). However, at least two other features might contribute to the effect. First, segmental duplications are frequent in the Arabidopsis genome (Arabidopsis Genome Initiative, 2000; Vision et al., 2000), somewhat more so than in the case of Drosophila or C. elegans, for instance. Second, plants, as sessile organisms, display a complex web of interactions with their environment (both biotic and abiotic), and many environmental variables evoke responses at the transcriptional level. In particular, and in contrast to animals, plant morphological development is, in many respects, a plastic process that is heavily influenced by the environment. A critical step in plant development is the floral transition, and the regulation of this switch is fundamentally different to the control of other developmental events that have well-defined end points, such as the patterning of a Drosophila embryo or a floral meristem. In these latter processes, which are very tractable to genetic studies, development is relatively 


\section{Light inputs}

(daylength, light quality)

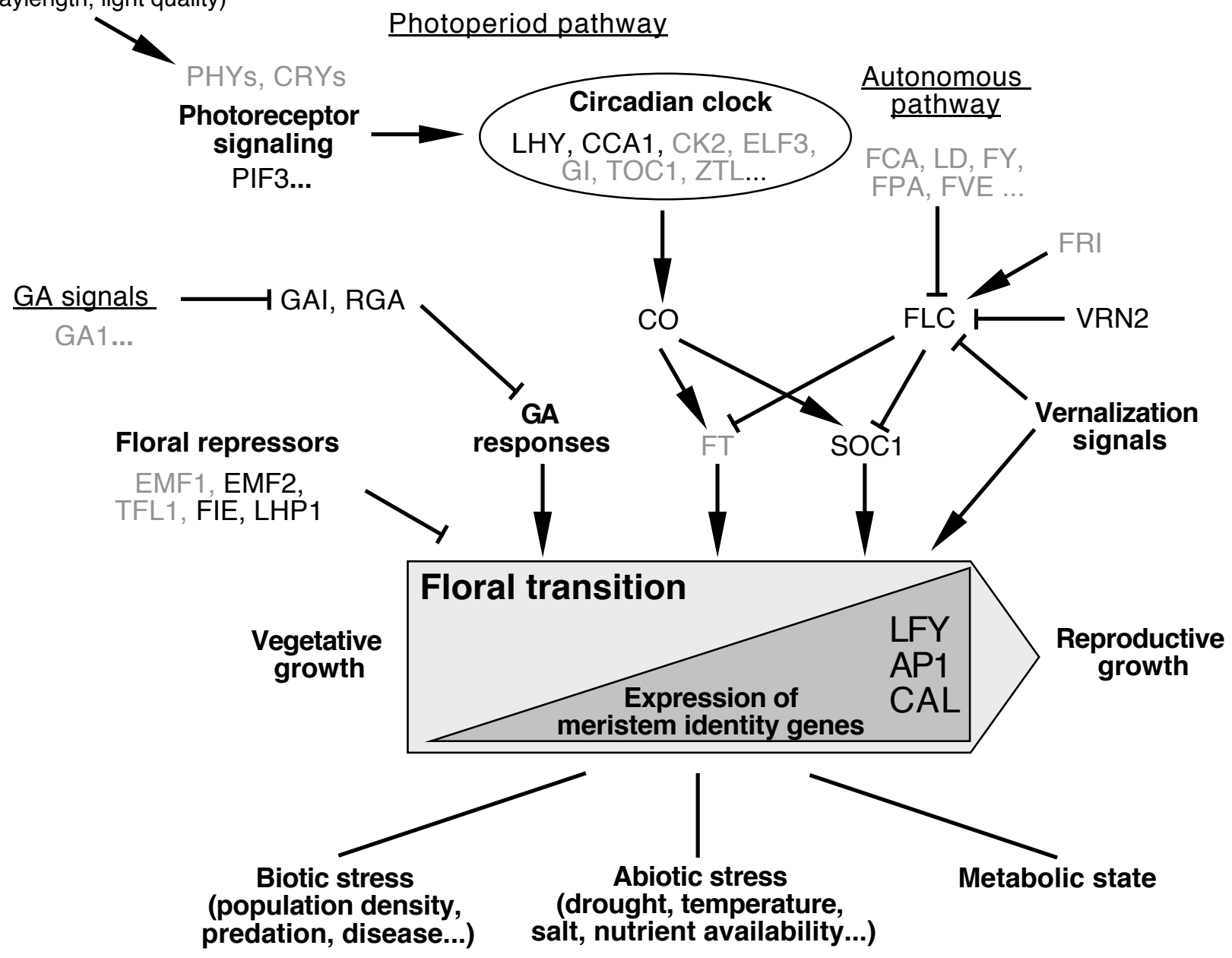

Figure 2. Control of the floral transition in Arabidopsis. The diagram represents a summary of the different pathways known to control the reproductive switch in Arabidopsis. The three major characterized pathways are the autonomous pathway (which monitors the developmental state of the plant), the photoperiod pathway (which mediates the response to light inputs, such as daylength), and the gibberellin pathway. Many variables that influence the floral transition (biotic and abiotic stress, metabolic state of the plant) remain to be studied, and the molecular mechanisms by which those inputs operate are not known. Some of the genes or loci that form the different pathways are listed; genes that code for transcription factors or chromatin related proteins are written in black, and those that code for other types of proteins are shown in gray. Some of these latter genes, however, might also be involved in transcriptional regulation, since they code for novel nuclear localized proteins (such as Gl, and ELF3). The multiple positive and negative inputs of the regulatory network are eventually resolved into the upregulation of meristem identity genes, such as $L F Y, A P 1$, and $C A L$. Arrows represent positive inputs, either at the physiological level (promotion of the floral transition) or at the molecular level (induction of gene expression or activity). Blunt-ended arrows represent negative inputs: repressors of the reproductive switch (physiological level), or of gene expression or activity (molecular level).

inflexible, and is achieved using the same sets of genes irrespective of the prevailing conditions. In contrast, although the reproductive switch is in itself a well-defined end point, flowering time is a highly plastic trait, and multiple channels exist via which the decision can be influenced by any of a number of very diverse inputs (Figure 1).

\section{Transcriptional Regulation and the Control of Flowering Time in Arabidopsis}

Genetic analyses of Arabidopsis mutants and natural variants (accessions and ecotypes) have identified several major pathways that regulate flowering time (Figure 2), including the photoperiod pathway, the autonomous pathway, and the gibberellin pathway (Koornneef et al., 1991; Martínez-Zapater et al., 1994; Koornneef et al., 1998; Reeves and Coupland, 2001). From our current knowledge, it appears that each one of these major pathways is founded upon key steps of transcriptional regulation. Ultimately, the flowering time regulatory pathways influence the expression of additional transcription factors that promote floral meristem development, such as LEAFY (LFY) and APETALA1 (AP1; a MADS domain protein) (Mandel et al., 1992; Weigel et al., 1992; Simon et al., 1996; Ruiz-García et al., 1997; Nilsson et al., 1998; Parcy et al., 1998). In fact, the promoter of the $L E A F Y$ gene serves as a convergence point for the different inductive pathways 
(Blázquez and Weigel, 2000), in accordance with the concept of promoters acting as information processing systems (reviewed in Riechmann, 2002). CONSTANS (CO) appears to be the central transcriptional regulator within the photoperiod pathway, whereas FLOWERING LOCUS C (FLC) and GIBBERELLIN INSENSITIVE (GAI) are key transcription factors within the autonomous and gibberellin pathways, respectively (Putterill et al., 1995; Peng et al., 1997; Michaels and Amasino, 1999a; Sheldon et al., 1999).

\section{Transcriptional Regulation Within the Photoperiod Pathway}

Arabidopsis is a facultative long day (LD) plant in which flowering is accelerated by daylengths of 16 or more hours light. Mutants such as $c o$, gigantea $(g i), f h a, f t, f d, f e$, and fwa are defective in this response (Rédei, 1962; Koornneef et al., 1991): they flower later than wild-type plants under inductive LD conditions, but flower at the same time as wild type when grown in short day (SD) conditions of 8 or 10 hours light. Additionally, these mutants show little or no response to vernalization, further indicating that the corresponding genes are specifically involved in the response to daylength.

$C O$ is a central component of the photoperiod floral promotion pathway (Figure 2), and a potent activator of flowering; 35S::COArabidopsis transgenic plants, in which the gene is constitutively expressed, flower extremely early under all photoperiodic conditions (Onouchi et al., 2000). COencodes a putative transcriptional regulator with a $\mathrm{C}_{2} \mathrm{C}_{2}$ zinc finger motif (Putterill et al., 1995), and defines a subfamily of 33 genes in Arabidopsis which, together with the GATA, Dof, and YABBY transcription factors, comprise the $\mathrm{C}_{2} \mathrm{C}_{2}$ superfamily (Riechmann et al., 2000). The molecular mechanism of $\mathrm{CO}$ action still remains to be elucidated, and one of the hallmarks of typical transcription factors (sequence-specific binding to DNA) has not been demonstrated yet for the $\mathrm{CO}$ protein. However, several lines of evidence suggest a direct role for $\mathrm{CO}$ in transcriptional regulation.

A glucocorticoid inducible system has been used to trigger CO activity in plants, to follow its effects on the expression of specific genes over time or, in combination with differential display, to identify putative $\mathrm{CO}$ targets (Simon et al., 1996; Samach et al., 2000). These experiments showed that upregulation of first $L E A F Y$, and then $A P 1$, occurs relatively rapidly following induction of CO activity, and identified SUPPRESSOR OF OVEREXPRESSION OF CONSTANS 1 (SOC1) and FT as early targets of $C O$. In an independent experiment, both soc 1 and $f t$ alleles were identified in mutagenesis screens as suppressors that attenuated the early flowering phenotype of $35 \mathrm{~S}:$ :CO transgenic lines, corroborating the conclusion that they act downstream of $\mathrm{CO}$ in the regulatory network to promote flowering (Onouchi et al., 2000).

The molecular mode of action of FT remains unclear, since it encodes a putative phosphatidyl ethanolamine binding protein of uncharacterized cellular role (Kardailsky et al., 1999; Kobayashi et al., 1999). However, SOC1 codes for a MADS domain transcription factor (SOC1 has also been described as AGAMOUS-LIKE 20, or AGL20, and was independently identified by two other groups as a positive regulator of flowering: Borner et al., 2000; Lee et al., 2000). FT and SOC1 likely represent integration points at which the different flowering pathways converge prior to upregulation of floral meristem identity genes (Figure 2) (Lee et al., 2000; Onouchi et al., 2000; Samach et al., 2000).

The suppressor mutagenesis screens performed with the 35S::CO transgenic lines also identified novel alleles of another gene, FWA, that attenuated the early flowering phenotype of the plants. Unlike $F T, S O C 1$, and $C O$ itself, FWA appears to act as a floral repressor, with late flowering fwa mutants corresponding to dominant gain of function alleles (Onouchi et al., 2000; Soppe et al., 2000). Additionally, null mutants for FWA appear wild-type, suggesting that it might act redundantly with another gene, or function in wild-type plants under very specific conditions (Soppe et al., 2000). FWA encodes a homeodomain transcription factor of the GL2 class (Soppe et al., 2000), that bears considerable homology to another GL2-like transcription factor, ANTHOCYANINLESS2 (ANL2) (Kubo et al., 1999). The anl2 loss-of-function mutant does not show alterations in flowering time, but displays a pleiotropic phenotype comprising defects in anthocyanin accumulation and in root development (Kubo et al., 1999). However, activation tagged Arabidopsis lines in which ANL2 is upregulated are late flowering (Weigel et al., 2000). Nevertheless, regardless of whether FWA and ANL2 correspond to bona fide flowering time loci or not, the fact that the upregulation or miss-expression of both genes alters flowering time, suggests that evolution could tinker with the trait by modifying the expression of genes that have other defined functions.

In summary, $C O$ is a central component of the photoperiod floral promotion pathway, which appears to depend heavily on transcriptional regulatory switches. But how is the activity of $C O$ regulated, and how are changes in light conditions detected and relayed into the pathway?

CO transcript levels show daily oscillations, falling following dawn and accumulating through the day, reaching high levels by the afternoon or evening (Suárez-López et al., 2001). Importantly, the ability of CO to activate target genes such as FT likely depends on whether $C O$ levels become high while the plants are still in a light period. In SD conditions, under which $\mathrm{CO}$ does not induce flowering, $\mathrm{CO}$ levels do not become sufficiently high until the plants are once again in darkness. Studies of $F T$ expression in LD grown 35S::CO lines show that FT mRNA abundance is much higher in the light than in the dark, indicating that light exposure might influence activity of the $\mathrm{CO}$ protein (Suárez-López et al., 2001). The rhythmic expression pattern of $C O$ indicates a role for the circadian clock in its regulation and, in fact, $C O$ transcript levels are altered, and expression becomes arrhythmic, in mutants for clockassociated genes, such as LATE ELONGATED HYPOCOTYL (LHY), EARLY FLOWERING 3 (ELF3), and GIGANTEA (GI) (Suárez-López et al., 2001). Thus, CO is itself a link between the circadian clock, which is entrained by light signals and measures light/dark cycles, and downstream floral promoters in the photoperiod pathway. This is illustrated by the observation that $F T$ transcript levels reflect those of CO (Suárez-López et al., 2001). 
Circadian clocks are considered to have three basic conceptual components. The first is an input pathway(s) that transmits information from the environment and sets the phase of a second component, the central oscillator, which in Drosophila and Neurospora crassa consists of a feedback loop comprising positive and negative elements. The final component is an output pathway that relays information from the clock to the many pathways and processes that it regulates (reviewed in: Barak et al., 2000; Harmer et al., 2001; McClung, 2001).

In Arabidopsis, a pair of homologous MYB-related transcription factors, LHY and CIRCADIAN CLOCK ASSOCIATED 1 (CCA1), appear to be components of the oscillator (Wang et al., 1997; Schaffer et al., 1998; Wang and Tobin, 1998). LHY and CCA1 show regular oscillations in transcript levels through the day/night cycle that persist if plants are moved into either continuous light or dark conditions, and both genes appear to display feedback inhibition of their own transcription. The constitutive expression of either CCA1 or $L H Y$ in transgenic plants causes late flowering, repression of the expression of the endogenous CCA1 and $L H Y$ genes, and many other alterations related to a disruption of clock function (Schaffer et al., 1998; Wang and Tobin, 1998). Another gene associated with the circadian clock in Arabidopsis is TOC1, which encodes a protein with a region that is also found in CO-like transcription factors, and another segment of similarity to the receiver domains of response regulators from two-component signal transduction systems (Makino et al., 2000; Strayer et al., 2000). The molecular mechanism of TOC1 action is somewhat unclear, but it has been shown that it forms a feedback loop with CCA1 and LHY that is critical for clock function. Both LHY and CCA1 can bind to a region within the TOC1 promoter, and they negatively regulate TOC1 expression; reciprocally, TOC1 appears to activate both its own transcription and that of $L H Y$ and CCA1 (Alabadí et al., 2001). In addition to their regulation at the transcriptional level, CCA1 and LHY also appear to be regulated by phosphorylation, and have been shown to associate with protein kinase CK2 (Sugano et al., 1999). Transgenic plants in which CKB3, a regulatory subunit of CK2, is overexpressed show altered flowering time and shorter periods of rhythmic expression of $C C A 1$ and $L H Y$, suggesting that CK2 can influence flowering via the circadian clock (Sugano et al., 1999).

The clock-associated genes ELF3 and GI have long been implicated in the photoperiodic regulation of flowering (Rédei, 1962; Koornneef et al., 1991; Zagotta et al., 1996; Fowler et al., 1999; Park et al., 1999; Huq et al., 2000; Covington et al., 2001; Hicks et al., 2001; Liu et al., 2001b). These genes have opposing effects, with ELF3 acting as a floral repressor and $G$ I functioning to promote the floral transition. Gl likely functions upstream of $C O$ (because overexpression of $\mathrm{CO}$ corrects the gi late flowering phenotype), and it encodes a novel nuclear localized protein (Fowler et al., 1999; Park et al., 1999; Huq et al., 2000). Glis expressed in a circadian pattern, and influences both its own transcription and expression of $L H Y$ and $C C A 1$ (Fowler et al., 1999; Park et al., 1999). ELF3 encodes a novel type of nuclear protein, is also under circadian control, and appears to inhibit both light signal inputs and clock outputs (Covington et al., 2001; Hicks et al., 2001; Liu et al., 2001b).

The main input, or entrainment stimulus, for the circadian clock in plants is light (reviewed in: Barak et al., 2000; Harmer et al., 2001; McClung, 2001), which is sensed by different classes of photoreceptors. Arabidopsis perceives light using different types of light-absorbing photoreceptors, such as phytochromes (phyA through phyE), which absorb red and far-red light, and cryptochromes (CRY1 and CRY2), which absorb blue and UV-A light (for review: Batschauer, 1998; Nagy and Schäfer, 2000). Because light conditions influence many different aspects of plant physiology and development, genes encoding photoreceptors and light-signaling components have frequently been characterized on the basis of mutants that show changes in seedling photomorphogenesis. However, many of these mutants (e.g. cop1, det1, det2, hy1, hy2, phyA, phyB, pef1, pef2, and pef3) also display alterations in flowering time (Levy and Dean, 1998b, and references therein). Conversely, a number of mutants (e.g. elf3, elg, Ihy, and fha) identified via alterations in flowering time display abnormalities in photomorphogenesis (Levy and Dean, 1998b, and references therein).

The photoreceptors phyA and CRY2 appear to have a prominent role in photoperiod perception, whereas phyB plays a major role in determining flowering time in response to light quality (Koornneef and Peeters, 1997; Guo et al., 1998). CRY2 is now known to be the product of the FHA gene (Guo et al., 1998), which was one of the initial set of flowering time loci that were placed in the photoperiod pathway (Koornneef et al., 1991). Accordingly, CRY2 appears to markedly influence $C O$ activity; $C O$ transcript levels are elevated in transgenic lines that overexpress $C R Y 2$, and lowered in the cry2 mutant (Guo et al., 1998). Levels of both phyA and CRY2 proteins fall rapidly in the light, further supporting the notion that they are involved in sensing light/dark transitions (Sharrock and Quail, 1989; Lin et al., 1998). CRY1 also has a role in the promotion of flowering, but its interaction with flowering time pathways is less clear (Bagnall et al., 1996; Koornneef and Peeters, 1997; Simpson et al., 1999). In addition, some photoreceptors likely influence flowering time independently of the circadian clock (Koornneef et al., 1995; Millar et al., 1995; Simpson et al., 1999).

Transcription factors are involved in photoreceptor signal transduction. PHYTOCHROME INTERACTING FACTOR3 (PIF3) is a transcription factor of the bHLH family that participates in signaling by phyB ( $\mathrm{Ni}$ et al., 1998; Halliday et al., 1999). PIF3 binds to a cis-element present in several light-regulated promoters, and phyB (which is translocated to the nucleus in a light dependent manner: Kircher et al., 1999; Yamaguchi et al., 1999) reversibly binds to DNA-bound PIF3 upon the light-triggered conversion to its biologically active form (Ni et al., 1998; Martínez-García et al., 2000; Zhu et al., 2000). Thus, phytochromes might act as light-switchable components of transcription complexes, and their interaction with transcription factors might provide a short, direct pathway from light perception to photoresponsive nuclear gene expression (MartínezGarcía et al., 2000). Plants in which PIF3 activity is reduced flower early, indicating that the gene is necessary for proper 
regulation of flowering time (Ni et al., 1998).

In summary, genetic analysis and gene expression studies on mutant and transgenic gain-of-function lines have revealed that regulation within the photoperiod pathway is heavily dependent on cascades of transcriptional activity mediated via the action of transcription factors. Such transcriptional regulatory events are central to the perceptions of the inputs for the pathway and to its initial steps (photoreceptor signal transduction and the circadian clock), to its global regulation (built around $\mathrm{CO}$ ), and to its downstream, effector steps. Pathway architecture that is based on transcriptional regulation also appears to be a recurring theme for the other known pathways that control the switch to flowering.

\section{Transcriptional Regulation Within the Autonomous Pathway}

The autonomous pathway monitors the developmental state of the plant and, in contrast to the photoperiod pathway, it does not respond to daylength (Koornneef et al., 1991; Martínez-Zapater et al., 1994). Loci that promote flowering within this pathway include LUMINIDEPENDENS $(L D), F C A, F Y, F P A, F V E$, and FLD; mutants for these genes flower later than wild-type plants in either long day or short day conditions. Additionally, two dominant factors that repress flowering, FLOWERING LOCUS C (FLC) and FRIGIDA (FRI), were identified via genetic analysis of naturally occurring early and late flowering ecotypes (Burn et al., 1993; Lee et al., 1993; Clarke and Dean, 1994; Koornneef et al., 1994; Lee et al., 1994; Lee and Amasino, 1995; Sanda and Amasino, 1996; Johanson et al., 2000). $F R I$ and $F L C$ act synergistically, and ecotypes that contain active alleles of both of these genes are very late flowering. Importantly, such ecotypes and late flowering autonomous pathway mutants display a strong vernalization response, and exhibit much earlier flowering if given a prolonged cold treatment of 4-8 weeks at the germinating seedling stage.

Many of the loci within the autonomous pathway have now been cloned (Figure 2). In a comparable manner to CO occupying a central role in the photoperiod pathway, FLC is a novel MADS domain transcription factor that has a central function within the autonomous pathway, acting as a repressor of the floral transition (Michaels and Amasino, 1999b; Sheldon et al., 1999; Michaels and Amasino, 2001). In particular, FLC plays an important role in the maintenance of a vernalization response, with $F L C$ transcript levels declining during cold treatments. In addition, it has been shown that overexpression of $F L C$ is sufficient to severely delay or even prevent flowering in early flowering Arabidopsis accessions, such as Landsberg erecta (Ler) and Columbia, in agreement with FLC acting as a repressor of the transition (Michaels and Amasino, 1999a; Sheldon et al., 1999; Ratcliffe et al., 2001). Plants carrying dominant $F R I$ alleles and autonomous pathway mutants all contain high steady state levels of FLC transcript. Thus, $F R I$ appears to support $F L C$ levels, and genes such as $\angle D, F C A$, and FVE have inhibitory effects (Michaels and Amasino, 1999b; Sheldon et al., 1999; Michaels and Amasino, 2001). FCA, FPA, and possibly also $L D$, encode putative RNA binding proteins and could therefore potentially regulate $F L C$ post-transcriptionally (Macknight et al., 1997; Aukerman et al., 1999; Schomburg et al., 2001). The cellular function of FRI is unknown, since it represents a novel type of protein (Johanson et al., 2000), and the molecular mechanisms by which $F L C$ transcript levels are reduced following cold treatments remain elusive.

Intriguingly, it seems likely that other genes could also act alongside $F L C$ in the maintenance of a vernalization response, since flc null mutants still respond to vernalization (Michaels and Amasino, 2001). It has recently been shown that the Arabidopsis genome encodes five other MADS domain transcription factors that are highly homologous to $F L C$, and it appears that these genes could perform similar functions (Ratcliffe et al., 2001; Scortecci et al., 2001). An additional MADS box gene, SHORT VEGETATIVE PHASE $(S V P)$, also acts as a floral repressor, although its position within the regulatory network has not been established (Hartmann et al., 2000). A key question is to identify the downstream components of the pathway through which FLC exerts floral repression. As mentioned above, it has been shown that the photoperiod and autonomous pathways converge on at least two genes, $F T$ and SOC1, prior to activation of floral meristem identity genes (Borner et al., 2000; Lee et al., 2000; Onouchi et al., 2000; Samach et al., 2000). However, it is likely that FLC acts through additional targets, in addition to influencing SOC1 and FT (Michaels and Amasino, 2001).

\section{Transcriptional Regulation Within the Gibberellin Pathway}

The third major characterized pathway of floral promotion operates in response to gibberellic acid (GA) signals. Many of the mutants that are defective in GA metabolism show alterations in flowering time. In Arabidopsis, there appears to be a critical requirement for gibberellins in short days; mutants such as ga-1, which are unable to synthesize GA, do not flower under such conditions (Wilson et al., 1992; Blázquez et al., 1998; Nilsson et al., 1998; Reeves and Coupland, 2001). In addition, triply mutant plants that are defective in the GA, autonomous, and photoperiod pathways do not flower under either long or short days, indicating that gibberellins are required for flowering under all photoperiodic conditions (Reeves and Coupland, 2001). Finally, the floral meristem identity gene $L E A F Y$ is rapidly upregulated in response to GA applications (Blázquez et al., 1998).

As in the case of the autonomous and photoperiod pathways, the GA pathway appears to be organized around key transcription factors. In particular, the GIBBERELLIN INSENSITIVE (GAI) and REPRESSOR OF GA1-3 (RGA) loci encode highly related transcription factors of the GRAS family that act as negative regulators of GA responses (Peng and Harberd, 1997; Harberd et al., 1998; Silverstone et al., 1998; Dill and Sun, 2001; King et al., 2001). GAl and RGA are themselves repressed by GA signals, thereby permitting responses to occur, a mode of action that resembles the manner by which $F L C$ acts within the autonomous pathway. Unlike FLC, however, which is downregulated at the transcriptional level in response to vernalization, GAI and RGA appear to be modulated 
posttranslationally on receipt of GA signals (Peng et al., 1997; Peng et al., 1999). The GAI and RGA proteins also provide an example of the recurring theme of functional redundancy (Dill and Sun, 2001; King et al., 2001); in numerous instances, spanning different biological pathways, key Arabidopsis transcription factors have highly related paralogs that serve partially overlapping functions (reviewed in Riechmann, 2002).

\section{A Genomic View of Flowering Time Regulation}

The picture that emerges from the current understanding of flowering time control in Arabidopsis is thus one of three major pathways that operate in response to different environmental or internal variables. In these three pathways, transcriptional regulation plays a prominent role, and evidence of interconnectivity (or 'cross-talk') between them is starting to accumulate (Figure 2). However, such an understanding has been derived from classical genetic and molecular studies that have focused on the effects of, and interactions between, a relatively small number of genes. Hence, our current models are likely to be incomplete. In particular, screens for loci affecting flowering have been performed in only a limited number of conditions. Many different biotic and abiotic variables that influence the reproductive switch remain to be examined, such as growth temperature, water availability, light intensity, and various other abiotic and biotic factors. If the photoperiod, autonomous, and gibberellin pathways are an example for what remains to be discovered, responses to these unexplored variables will also likely be controlled by specific genes, and transcriptional regulation will be found to play a prominent role in each process. Thus, it is very probable that a substantial number of novel regulators of flowering time remain to be identified, and that a large proportion of them will be transcription factors. Importantly, the control of the transcriptional regulation events that control the floral transition has not been delegated to a single, or a few, transcription factor families. Rather, regulators that belong to many different gene families are involved in the process (Table 1). In addition, functional overlap or redundancy appears to be relatively common in Arabidopsis, and it has already been demonstrated, in several instances, for transcription factor genes (reviewed in Riechmann, 2002). This peculiarity, derived from the abundance of segmental duplications in the Arabidopsis genome (Vision et al., 2000), suggests that many important loci might have been missed in forward genetic screens. A potential example is provided by the transcription factor SPL3, a member of the SBP family (for SQUAMOSA promoter binding protein). SPL3 triggers early flowering when overexpressed, but plants in which its activity is reduced through antisense RNA display a wild-type phenotype (Cardon et al., 1997).

In summary, the list of regulatory components that control the reproductive switch in Arabidopsis is incomplete. In addition, little progress has been made in understanding the genome-wide changes that occur at the transition. Despite such limited knowledge, evidence has begun to accumulate indicating that the reproductive switch indeed involves broad ranging effects in the genome. Large-scale alterations in gene expression in response to light signals, and the involvement of chromatin associated proteins and of other epigenetic changes, such as DNA methylation, in flowering time regulation, appear to point in that direction.

\section{Genome-Wide Alterations in Gene Expression in Response} to Light Signals

DNA microarrays that monitor up to $\sim 8,500$ different Arabidopsis genes, or approximately one third of the genome, have been used in experiments designed to catalogue genes that are expressed in response to particular stresses or stimuli, or in certain tissues or developmental processes. These early studies have included the response to different nutrient concentrations, to drought and cold stresses, to wounding and insect feeding, the disease response, and light-related processes, such as the circadian clock, the light/dark transition, and phytochrome A signaling (reviewed in Riechmann, 2002). The most extensive dynamic reprogramming of the expression of the genome has been observed upon light stimulus or in light-related processes (Harmer et al., 2000; Ma et al., 2001; Schaffer et al., 2001; Tepperman et al., 2001). For example, one of these studies showed that up to $6 \%$ of the genes represented in the microarray exhibited circadian regulation (Harmer et al., 2000), and other experiments revealed that up to one third of genes were regulated by light (Ma et al., 2001). Furthermore, transcription factors appear to play a very significant role in phytochrome signaling: more than $40 \%$ of the genes that were immediately activated by the phyA pathway in response to a far-red light treatment were transcription factors (Tepperman et al., 2001). This result illustrates how a change in light conditions could be rapidly converted into differential regulation of expression of batteries of genes further down the response pathways.

\section{Chromatin Associated Proteins in Flowering Time Control}

The involvement of genome-wide transcriptional regulation in the control of flowering time is further suggested by the identification of a variety of chromatin associated proteins as important components of the machinery that controls the reproductive switch. Two well-established flowering time Ioci, EMBRYONIC FLOWER 2 (EMF2) and VERNALIZATION 2 (VRN2), encode zinc finger proteins similar to the Drosophila Polycomb Group (PcG) protein Suppressor of zeste $12(\mathrm{Su}(\mathrm{z}) 12)$, and likely act to maintain repressed states of gene expression (Birve et al., 2001; Gendall et al., 2001; Yoshida et al., 2001). VRN2 is required to maintain the stable reduction in $F L C$ transcript levels that occurs following vernalization treatments, and this appears to involve a change in chromatin accessibility at the FLC locus (Gendall et al., 2001). However, it is not known whether VRN2 acts specifically on FLC, or on a broader range of targets within the genome. EMF2 is critical for the general repression of flowering that occurs during seedling development, as mutants for this gene lack a rosette phase and flower very early, immediately following 
germination (Sung et al., 1992; Yang et al., 1995; Yoshida et al., 2001). Another Arabidopsis protein that, like EMF2, is involved in floral repression in early development is FERTILIZATION INDEPENDENT ENDOSPERM (FIE) (Kinoshita et al., 2001). FIE shows homology to PcG proteins with WD repeats, such as Drosophila extra sex combs (esc) (Ohad et al., 1999). Both EMF2 and FIE repress floral meristem and organ identity genes at early seedling stages, but whether this occurs directly or indirectly is not yet clear (Chen et al., 1997; Kinoshita et al., 2001; Yoshida et al., 2001).

Mutations in LIKE HETEROCHROMATIN PROTEIN 1 (LHP1), which codes for a homolog of Drosophila heterochromatin protein 1 (HP1), affect flowering time and plant architecture (Gaudin et al., 2001). Drosophila HP1 is involved in silencing gene expression through the generation and maintenance of inactive heterochromatin states (reviewed in Eissenberg and Elgin, 2000). The structural hallmark of HP1 proteins is the presence of two conserved domains, the chromo domain and the related chromo-shadow domain, both of which are critical for protein function. Arabidopsis LHP1 contains both domains and is a typical member of the HP1 family, and thus likely operates in a similar manner to HP1 (Gaudin et al., 2001). Arabidopsis Ihp1 mutants flower much earlier than wildtype plants, both in SD and in LD conditions, and show a reduced response to the influence of photoperiod. This result could be explained, at least in part, because $C O$ is upregulated in the Ihp1 mutant at the early stages of seedling development (two cotyledon stage), at which point CO expression levels are very low in wild-type plants (Gaudin et al., 2001). However, LHP1 shows subnuclear localization in distinct foci, suggesting the existence of multiple targets within the genome (Gaudin et al., 2001).

In summary, and as exemplified by EMF2, FIE, and LHP1, it appears that chromatin related proteins play critical roles in maintaining the vegetative phase of plant development through repression of gene expression, and thus the pathways that promote the floral transition must ultimately overcome this repression. Where transcription factors act as repressors of the reproductive switch, as in the case of FLC, chromatin related proteins might operate to decrease their expression, and thus to promote flowering by repressing a repressor, as exemplified by VRN2. In addition, some genes coding for other types of chromatin associated proteins might be involved in the control of the reproductive switch, since alteration in their activity results in flowering time defects. For instance, Arabidopsis plants in which transcript levels of AtHD1 (a histone deacetylasecoding gene, also referred to as AtRPD3A) were reduced, by using antisense RNA, were late flowering (Wu et al., 2000). Similarly, Arabidopsis lines in which DNA methylation (another epigenetic change that influences transcription levels) is reduced also display an abnormal flowering time (Ronemus et al., 1996). In both cases, it is not clear whether such phenotypes arise from broad-spectrum alterations in transcriptional activity across the entire genome, or from changes in the activity of a few key regulatory loci.

\section{Genetics, Genomics, and Regulatory Networks}

The view of flowering time regulation that is unfolding, then, mostly from studies in Arabidopsis, is one in which a large number of diverse stimuli are integrated via genetic networks that are centered upon, or based on, regulation at the transcriptional level. Given that only a limited set of conditions or variables has been analyzed, a large number of loci that impact the decision to flower likely remain to be discovered. A complex gene regulatory network probably exists underlying the control of flowering time, and such a network might be only partially captured in the current regulatory models, which are mostly based on linear genetic pathways. The flowering time regulatory network might turn out to be one of the most complex regulatory systems in a plant, perhaps together with that of the disease responses. The shape of the network itself is an open question, but it appears that information is eventually resolved into the upregulation of a small number of transcription factor genes, such as LFY, AP1, and CAULIFLOWER (CAL) (Mandel et al., 1992; Weigel et al., 1992; Kempin et al., 1995; Parcy et al., 1998), that control the development of floral meristems. In turn, these factors trigger the activity of larger numbers of downstream genes that pattern the meristem into whorls of floral organs (Figure 1).

The extent to which the regulation of flowering time in Arabidopsis also represents that of diverse plant species is still an open question. It is possible that some areas of the regulatory network (i.e., pathways) play more prominent roles in some plant species than in others, and that the mode by which the pathways or their components operate has been altered through evolution. For instance, $C O$ is the central component of the photoperiod pathway in Arabidopsis, which is a facultative long day plant (flowering is promoted by long days). Similarly, $C O$ homologs also appear to regulate the photoperiod flowering response in rice and in Pharbitis nil, which are short day plants (flowering is induced by long nights) (Yano et al., 2000; Liu et al., 2001a). How CO and orthologous genes regulate the photoperiod pathway in response to either long days or short days in different plant species is not clear, although it appears likely that changes at the level of transcriptional regulation, and not of protein sequence, are involved (reviewed in Samach and Gover, 2001). Interestingly, the expression of Pharbitis $C O$ correlates with the SD requirement for flowering, since it is increased by long nights; conversely, Arabidopsis CO expression is promoted by long days. Thus, $\mathrm{CO}$, and its role in the floral transition in diverse species, could provide another example of the importance of alterations in gene expression as a major source of the diversity and change that underlie the adaptation and evolution of eukaryotic organisms (Doebley and Lukens, 1998; Cubas et al., 1999; Carroll, 2000; Tautz, 2000).

In contrast to the case of the photoperiod pathway and of its components, whether regulation of the vernalization response is conserved between Arabidopsis and other plant species is still unclear. Furthermore, Arabidopsis is an annual plant whereas many other species exhibit a perennial growth habit. In Arabidopsis, floral meristem initiation is rapidly followed by flower emergence, whereas 
in numerous woody perennials, floral meristems arrest development for long periods following their initiation (Sedgley and Griffin, 1989). In many cases, it is not the actual initiation of floral meristems, but rather the time at which the dormancy of those meristems is broken, that is heavily dependent on the environmental conditions (Battey, 2000; Battey and Tooke, 2002). It has been suggested that the annual habit evolved from that of the perennial plants (Battey, 2000; Battey and Tooke, 2002). It is thus possible that regulatory genes exist within the Arabidopsis genome that are specific to annuals and that and are not represented in perennial plants. Alternatively, numerous genes involved in modulating perennialism might still be present in the Arabidopsis genome, but having a much less prominent regulatory role than in the ancestral species. If such loci exist, it is unlikely that they would be revealed in mutant screens performed under standard growth conditions.

To conclude, genome-wide approaches, made feasible by the availability of the Arabidopsis genome sequence (and of those of other plants in the future), and by the novel genomic techniques, offer the opportunity of a broader understanding of the control of the floral transition. Given the importance of transcriptional regulation in the pathways that are being elucidated, it appears that the network that regulates this developmental switch will eventually be interpreted and explained in terms of changes in transcriptional activity at a genome-wide level.

\section{References}

Adams, M.D., Celniker, S.E., Holt, R.A., Evans, C.A., Gocayne, J.D., Amanatides, P.G., Scherer, S.E., Li, P.W., Hoskins, R.A., Galle, R.F. et al. 2000. The genome sequence of Drosophila melanogaster. Science 287: 2185-2195.

Ahmad, M., and Cashmore, A.R. 1993. HY4 gene of Arabidopsis thaliana encodes a protein with characteristics of a blue-light photoreceptor. Nature 366: 162-166.

Alabadí, D., Oyama, T., Yanovsky, M.J., Harmon, F.G., Más, P., and Kay, S.A. 2001. Reciprocal regulation between TOC1 and LHY/CCA1 within the Arabidopsis circadian clock. Science 293: 880-883.

Arabidopsis Genome Initiative. 2000. Analysis of the genome sequence of the flowering plant Arabidopsis thaliana. Nature 408: 796-815.

Aubert, D., Chen, L., Moon, Y.H., Martin, D., Castle, L.A., Yang, C.H., and Sung, Z.R. 2001. EMF1, a novel protein involved in the control of shoot architecture and flowering in Arabidopsis. Plant Cell 13: 1865-1875.

Aukerman, M.J., Lee, I., Weigel, D., and Amasino, R.M. 1999. The Arabidopsis flowering-time gene LUMINIDEPENDENS is expressed primarily in regions of cell proliferation and encodes a nuclear protein that regulates $\angle E A F Y$ expression. Plant J. 18: 195-203.

Bagnall, D.J., King, R.W., and Hangarter, R.P. 1996. Bluelight promotion of flowering is absent in hy4 mutants of Arabidopsis. Planta 200: 278-280.

Barak, S., Tobin, E.M., Andronis, C., Sugano, S., and
Green, R.M. 2000. All in good time: the Arabidopsis circadian clock. Trends Plant Sci. 5: 517-522.

Batschauer, A. 1998. Photoreceptors of higher plants. Planta 206: 479-492.

Battey, N.H. 2000. Aspects of seasonality. J. Exp. Bot. 51: 1769-1780.

Battey, N.H., and Tooke, F. 2002. Molecular control and variation in the floral transition. Curr. Opin. Plant. Biol. 5: 62-68.

Birve, A., Sengupta, A.K., Beuchle, D., Larsson, J., Kennison, J.A., Rasmuson-Lestander, A., and Muller, J. 2001. Su(z) 12, a novel Drosophila Polycomb group gene that is conserved in vertebrates and plants. Development 128: 3371-3379.

Blázquez, M.A., Green, R., Nilsson, O., Sussman, M.R., and Weigel, D. 1998. Gibberellins promote flowering of Arabidopsis by activating the $L E A F Y$ promoter. Plant Cell 10: 791-800.

Blázquez, M.A., and Weigel, D. 2000. Integration of floral inductive signals in Arabidopsis. Nature 404: 889-892.

Borner, R., Kampmann, G., Chandler, J., Gleissner, R., Wisman, E., Apel, K., and Melzer, S. 2000. A MADS domain gene involved in the transition to flowering in Arabidopsis. Plant J. 24: 591-599.

Bradley, D., Ratcliffe, O., Vincent, C., Carpenter, R., and Coen, E. 1997. Inflorescence commitment and architecture in Arabidopsis. Science 275: 80-83.

Burn, J.E., Smyth, D.R., Peacock, W.J., and Dennis, E.S. 1993. Genes conferring late flowering in Arabidopsis thaliana. Genetica 90: 147-155.

Cardon, G.H., Hohmann, S., Nettesheim, K., Saedler, H., and Huijser, P. 1997. Functional analysis of the Arabidopsis thaliana SBP-box gene SPL3: a novel gene involved in the floral transition. Plant J. 12: 367-377.

Carroll, S.B. 2000. Endless forms: the evolution of gene regulation and morphological diversity. Cell 101:577-580.

Carroll, S.B. 2001. Chance and necessity: the evolution of morphological complexity and diversity. Nature 409: 11021109.

Chen, L., Cheng, J.C., Castle, L., and Sung, Z.R. 1997. EMF genes regulate Arabidopsis inflorescence development. Plant Cell 9: 2011-2024.

Clarke, J.H., and Dean, C. 1994. Mapping FRI, a locus controlling flowering time and vernalization response in Arabidopsis thaliana. Mol. Gen. Genet. 242: 81-89.

Claverie, J.-M. 2001. What if there are only 30,000 human genes? Science 291: 1255.

Covington, M.F., Panda, S., Liu, X.L., Strayer, C.A., Wagner, D.R., and Kay, S.A. 2001. ELF3 modulates resetting of the circadian clock in Arabidopsis. Plant Cell 13: 13051315.

Cubas, P., Vincent, C., and Coen, E. 1999. An epigenetic mutation responsible for natural variation in floral symmetry. Nature 401: 157-161.

Dill, A., and Sun, T.-p. 2001. Synergistic derepression of gibberellin signaling by removing $R G A$ and $G A$ / function in Arabidopsis thaliana. Genetics 159: 777-785.

Doebley, J., and Lukens, L. 1998. Transcriptional regulators and the evolution of plant form. Plant Cell 10: 1075-1082.

Eissenberg, J.C., and Elgin, S.C.R. 2000. The HP1 protein family: getting a grip on chromatin. Curr. Opin. Genet. 
Dev. 10: 204-210.

Fowler, S., Lee, K., Onouchi, H., Samach, A., Richardson, K., Morris, B., Coupland, G., and Putterill, J. 1999. GIGANTEA: a circadian clock-controlled gene that regulates photoperiodic flowering in Arabidopsis and encodes a protein with several possible membranespanning domains. EMBO J. 18: 4679-4688.

Fridborg, I., Kuusk, S., Moritz, T., and Sundberg, E. 1999. The Arabidopsis dwarf mutant shi exhibits reduced gibberellin responses conferred by overexpression of a new putative zinc finger protein. Plant Cell 11: 1019-1032. Gaudin, V., Libault, M., Pouteau, S., Juul, T., Zhao, G., Lefebvre, D., and Grandjean, O. 2001. Mutations in LIKE HETEROCHROMATIN PROTEIN 1 affect flowering time and plant architecture in Arabidopsis. Development 128: 4847-4858.

Gendall, A.R., Levy, Y.Y., Wilson, A., and Dean, C. 2001. The VERNALIZATION 2 gene mediates the epigenetic regulation of vernalization in Arabidopsis. Cell 107: 525535.

Guo, H., Yang, H., Mockler, T.C., and Lin, C. 1998. Regulation of flowering time by Arabidopsis photoreceptors. Science 279: 1360-1363.

Halliday, K.J., Hudson, M., Ni, M., Qin, M., and Quail, P.H. 1999. poc1: an Arabidopsis mutant perturbed in phytochrome signaling because of a T DNA insertion in the promoter of PIF3, a gene encoding a phytochromeinteracting bHLH protein. Proc. Natl. Acad. Sci. U. S. A. 96: 5832-5837.

Harberd, N.P., King, K.E., Carol, P., Cowling, R.J., Peng, J., and Richards, D.E. 1998. Gibberellin: inhibitor of an inhibitor of...? Bioessays 20: 1001-1008.

Harmer, S.L., Hogenesch, J.B., Straume, M., Chang, H.S., Han, B., Zhu, T., Wang, X., Kreps, J.A., and Kay, S.A. 2000. Orchestrated transcription of key pathways in Arabidopsis by the circadian clock. Science 290: 21102113.

Harmer, S.L., Panda, S., and Kay, S.A. 2001. Molecular bases of circadian rhythms. Annu. Rev. Cell Dev. Biol. 17: $215-253$

Hartmann, U., Hohmann, S., Nettesheim, K., Wisman, E., Saedler, H., and Huijser, P. 2000. Molecular cloning of SVP: a negative regulator of the floral transition in Arabidopsis. Plant J. 21: 351-360.

Hicks, K.A., Albertson, T.M., and Wagner, D.R. 2001. EARLY FLOWERING3 encodes a novel protein that regulates circadian clock function and flowering in Arabidopsis. Plant Cell 13: 1281-1292.

Hogenesch, J.B., Ching, K.A., Batalov, S., Su, A.I., Walker, J.R., Zhou, Y., Kay, S.A., Schultz, P.G., and Cooke, M.P. 2001. A comparison of the Celera and Ensembl predicted gene sets reveals little overlap in novel genes. Cell 106: 413-415.

Huq, E., Tepperman, J.M., and Quail, P.H. 2000. GIGANTEA is a nuclear protein involved in phytochrome signaling in Arabidopsis. Proc. Natl. Acad. Sci. U. S. A. 97: 9789-9794.

International Human Genome Sequencing Consortium. 2001. Initial sequencing and analysis of the human genome. Nature 409: 860-921.

Johanson, U., West, J., Lister, C., Michaels, S., Amasino,
R., and Dean, C. 2000. Molecular analysis of FRIGIDA, a major determinant of natural variation in Arabidopsis flowering time. Science 290: 344-347.

Kania, T., Russenberger, D., Peng, S., Apel, K., and Melzer, S. 1997. FPF1 promotes flowering in Arabidopsis. Plant Cell 9: 1327-1338.

Kardailsky, I., Shukla, V.K., Ahn, J.H., Dagenais, N., Christensen, S.K., Nguyen, J.T., Chory, J., Harrison, M.J., and Weigel, D. 1999. Activation tagging of the floral inducer FT. Science 286: 1962-1965.

Kempin, S.A., Savidge, B., and Yanofsky, M.F. 1995. Molecular basis of the cauliflower phenotype in Arabidopsis. Science 267: 522-525.

King, K.E., Moritz, T., and Harberd, N.P. 2001. Gibberellins are not required for normal stem growth in Arabidopsis thaliana in the absence of GAI and RGA. Genetics 159: 767-776.

Kinoshita, T., Harada, J.J., Goldberg, R.B., and Fischer, R.L. 2001. Polycomb repression of flowering during early plant development. Proc. Natl. Acad. Sci. U. S. A. 98: 14156-14161.

Kircher, S., Kozma-Bognar, L., Kim, L., Adam, E., Harter, K., Schäfer, E., and Nagy, F. 1999. Light quality-dependent nuclear import of the plant photoreceptors phytochrome A and B. Plant Cell 11: 1445-1456.

Kobayashi, Y., Kaya, H., Goto, K., Iwabuchi, M., and Araki, T. 1999. A pair of related genes with antagonistic roles in mediating flowering signals. Science 286: 1960-1962.

Koornneef, M., Hanhart, C.J., and van der Veen, J.H. 1991. A genetic and physiological analysis of late flowering mutants in Arabidopsis thaliana. Mol. Gen. Genet. 229: 57-66.

Koornneef, M., Blankestijn-de Vries, H., Hanhart, C.J., Soppe, W., and Peeters, A.J.M. 1994. The phenotype of some late-flowering mutants is enhanced by a locus on chromosome 5 that is not effective in the Landsberg erecta wild-type. Plant J. 6: 911-919.

Koornneef, M., Hanhart, C.J., van Loenen-Martinet, P., and Blankestijn-de Vries, H. 1995. The effect of daylength on the transition to flowering in phytochrome deficient, late flowering and double mutants of Arabidopsis thaliana. Physiol. Plant. 95: 260-266.

Koornneef, M., and Peeters, A.J.M. 1997. Floral transition mutants in Arabidopsis. Plant Cell Environ. 20: 779-784.

Koornneef, M., Alonso-Blanco, C., Peeters, A.J.M., and Soppe, W. 1998. Genetic control of flowering time in Arabidopsis. Annu. Rev. Plant Physiol. Plant Mol. Biol. 49: 345-370.

Kubo, H., Peeters, A.J., Aarts, M.G., Pereira, A., and Koornneef, M. 1999. ANTHOCYANINLESS2, a homeobox gene affecting anthocyanin distribution and root development in Arabidopsis. Plant Cell 11: 12171226.

Lee, H., Suh, S.S., Park, E., Cho, E., Ahn, J.H., Kim, S.G., Lee, J.S., Kwon, Y.M., and Lee, I. 2000. The AGAMOUSLIKE 20 MADS domain protein integrates floral inductive pathways in Arabidopsis. Genes Dev. 14: 2366-2376.

Lee, I., Bleecker, A., and Amasino, R. 1993. Analysis of naturally occurring late flowering in Arabidopsis thaliana. Mol. Gen. Genet. 237: 171-176.

Lee, I., Aukerman, M.J., Gore, S.L., Lohman, K.N., 
Michaels, S.D., Weaver, L.M., John, M.C., Feldmann, K.A., and Amasino, R.M. 1994. Isolation of LUMINIDEPENDENS: a gene involved in the control of flowering time in Arabidopsis. Plant Cell 6: 75-83.

Lee, I., and Amasino, R.M. 1995. Effect of vernalization, photoperiod, and light quality on the flowering phenotype of Arabidopsis plants containing the FRIGIDA gene. Plant Physiol. 108: 157-162.

Levy, Y.Y., and Dean, C. 1998a. Control of flowering time. Curr. Opin. Plant. Biol. 1: 49-54.

Levy, Y.Y., and Dean, C. 1998b. The transition to flowering. Plant Cell 10: 1973-1990.

Lin, C., Yang, H., Guo, H., Mockler, T., Chen, J., and Cashmore, A.R. 1998. Enhancement of blue-light sensitivity of Arabidopsis seedlings by a blue light receptor cryptochrome 2. Proc. Natl. Acad. Sci. U. S. A. 95: 26862690.

Lin, X., Kaul, S., Rounsley, S., Shea, T.P., Benito, M.I., Town, C.D., Fujii, C.Y., Mason, T., Bowman, C.L., Barnstead, M. et al. 1999. Sequence and analysis of chromosome 2 of the plant Arabidopsis thaliana. Nature 402: 761-768.

Liu, J., Yu, J., Mclntosh, L., Kende, H., and Zeevaart, J.A.D. 2001a. Isolation of a CONSTANS ortholog from Pharbitis nil and its role in flowering. Plant Physiol. 125: 1821-1830.

Liu, X.L., Covington, M.F., Fankhauser, C., Chory, J., and Wagner, D.R. 2001b. ELF3 encodes a circadian clockregulated nuclear protein that functions in an Arabidopsis PHYB signal transduction pathway. Plant Cell 13: 12931304.

Ma, L.-G., Li, J., Qu, L., Hager, J., Chen, Z., Zhao, H., and Deng, X.W. 2001. Light control of Arabidopsis development entails coordinated regulation of genome expression and cellular pathways. Plant Cell 13: 25892607.

Macknight, R., Bancroft, I., Page, T., Lister, C., Schmidt, R., Love, K., Westphal, L., Murphy, G., Sherson, S., Cobbett, C. et al. 1997. FCA, a gene controlling flowering time in Arabidopsis, encodes a protein containing RNAbinding domains. Cell 89: 737-745.

Makino, S., Kiba, T., Imamura, A., Hanaki, N., Nakamura, A., Suzuki, T., Taniguchi, M., Ueguchi, C., Sugiyama, T., and Mizuno, T. 2000. Genes encoding pseudo-response regulators: Insight into His-to-Asp phosphorelay and circadian rhythm in Arabidopsis thaliana. Plant Cell Physiol. 41: 791-803.

Mandel, M.A., Gustafson-Brown, C., Savidge, B., and Yanofsky, M.F. 1992. Molecular characterization of the Arabidopsis floral homeotic gene APETALA1. Nature 360: 273-277.

Martínez-García, J.F., Huq, E., and Quail, P.H. 2000. Direct targeting of light signals to a promoter element-bound transcription factor. Science 288: 859-863.

Martínez-Zapater, J.M., Coupland, G., Dean, C., and Koornneef, M. 1994. The transition to flowering in Arabidopsis. In: Arabidopsis. Meyerowitz, E.M. and Somerville, C., eds. Cold Spring Harbor Laboratory Press, New York, p. 403-433.

Mayer, K., Schuller, C., Wambutt, R., Murphy, G., Volckaert, G., Pohl, T., Dusterhoft, A., Stiekema, W., Entian, K.D., Terryn, N. et al. 1999. Sequence and analysis of chromosome 4 of the plant Arabidopsis thaliana. Nature 402: 769-777.

McClung, C.R. 2001. Circadian Rhythms in Plants. Annu. Rev. Plant Physiol. Plant Mol. Biol. 52: 139-162.

Michaels, S.D., and Amasino, R.M. 1999a. FLOWERING LOCUS $C$ encodes a novel MADS domain protein that acts as a repressor of flowering. Plant Cell 11: 949-956.

Michaels, S.D., and Amasino, R.M. 1999b. The gibberellic acid biosynthesis mutant ga1-3 of Arabidopsis thaliana is responsive to vernalization. Dev. Genet. 25: 194-198.

Michaels, S.D., and Amasino, R.M. 2001. Loss of FLOWERING LOCUS $C$ activity eliminates the lateflowering phenotype of frigida and autonomous pathway mutations but not responsiveness to vernalization. Plant Cell 13: 935-942.

Millar, A.J., Straume, M., Chory, J., Chua, N.H., and Kay, S.A. 1995. The regulation of circadian period by phototransduction pathways in Arabidopsis. Science 267: 1163-1166.

Nagy, F., and Schäfer, E. 2000. Nuclear and cytosolic events of light-induced, phytochrome regulated signaling in higher plants. EMBO J. 19: 157-163.

Nelson, D.C., Lasswell, J., Rogg, L.E., Cohen, M.A., and Bartel, B. 2000. FKF1, a clock-controlled gene that regulates the transition to flowering in Arabidopsis. Cell 101: 331-340.

Ni, M., Tepperman, J.M., and Quail, P.H. 1998. PIF3, a phytochrome-interacting factor necessary for normal photoinduced signal transduction, is a novel basic helixloop-helix protein. Cell 95: 657-667.

Nilsson, O., Lee, I., Blázquez, M.A., and Weigel, D. 1998. Flowering-time genes modulate the response to $L E A F Y$ activity. Genetics 150: 403-410.

Ohad, N., Yadegari, R., Margossian, L., Hannon, M., Michaeli, D., Harada, J.J., Goldberg, R.B., and Fischer, R.L. 1999. Mutations in FIE, a WD polycomb group gene, allow endosperm development without fertilization. Plant Cell 11: 407-416.

Onouchi, H., Igeño, M.I., Perilleux, C., Graves, K., and Coupland, G. 2000. Mutagenesis of plants overexpressing CONSTANS demonstrates novel interactions among Arabidopsis flowering-time genes. Plant Cell 12: 885-900.

Parcy, F., Nilsson, O., Busch, M.A., Lee, I., and Weigel, D. 1998. A genetic framework for floral patterning. Nature 395: 561-566.

Park, D.H., Somers, D.E., Kim, Y.S., Choy, Y.H., Lim, H.K., Soh, M.S., Kim, H.J., Kay, S.A., and Nam, H.G. 1999. Control of circadian rhythms and photoperiodic flowering by the Arabidopsis GIGANTEA gene. Science 285: 15791582.

Peng, J., Carol, P., Richards, D.E., King, K.E., Cowling, R.J., Murphy, G.P., and Harberd, N.P. 1997. The Arabidopsis $G A /$ gene defines a signaling pathway that negatively regulates gibberellin responses. Genes Dev. 11: 3194-3205.

Peng, J., and Harberd, N.P. 1997. Gibberellin deficiency and response mutations suppress the stem elongation phenotype of phytochrome-deficient mutants of Arabidopsis. Plant Physiol. 113: 1051-1058.

Peng, J., Richards, D.E., Hartley, N.M., Murphy, G.P., Devos, K.M., Flintham, J.E., Beales, J., Fish, L.J., 
Worland, A.J., Pelica, F. et al. 1999. 'Green revolution' genes encode mutant gibberellin response modulators. Nature 400: 256-261.

Putterill, J., Robson, F., Lee, K., Simon, R., and Coupland, G. 1995. The CONSTANS gene of Arabidopsis promotes flowering and encodes a protein showing similarities to zinc finger transcription factors. Cell 80: 847-857.

Ratcliffe, O.J., Nadzan, G.C., Reuber, T.L., and Riechmann, J.L. 2001. Regulation of flowering in Arabidopsis by an FLC homologue. Plant Physiol. 126: 122-132.

Rédei, G.P. 1962. Supervital mutants of Arabidopsis. Genetics 47: 443-460.

Reeves, P.H., and Coupland, G. 2000. Response of plant development to environment: control of flowering by daylength and temperature. Curr. Opin. Plant. Biol. 3: 3742.

Reeves, P.H., and Coupland, G. 2001. Analysis of flowering time control in Arabidopsis by comparison of double and triple mutants. Plant Physiol. 126: 1085-1091.

Riechmann, J.L., Heard, J., Martin, G., Reuber, L., Jiang, C., Keddie, J., Adam, L., Pineda, O., Ratcliffe, O.J., Samaha, R.R. et al. 2000. Arabidopsis transcription factors: genome-wide comparative analysis among eukaryotes. Science 290: 2105-2110.

Riechmann, J.L., and Ratcliffe, O.J. 2000. A genomic perspective on plant transcription factors. Curr. Opin. Plant. Biol. 3: 423-434.

Riechmann, J.L. 2002. Transcriptional regulation: a genomic overview. In: The Arabidopsis Book. Somerville, C.R. and Meyerowitz, E.M., eds. In preparation.

Ronemus, M.J., Galbiati, M., Ticknor, C., Chen, J., and Dellaporta, S.L. 1996. Demethylation-induced developmental pleiotropy in Arabidopsis. Science 273: 654-657.

Ruiz-García, L., Madueño, F., Wilkinson, M., Haughn, G., Salinas, J., and Martínez-Zapater, J.M. 1997. Different roles of flowering-time genes in the activation of floral initiation genes in Arabidopsis. Plant Cell 9: 1921-1934. Salanoubat, M., Lemcke, K., Rieger, M., Ansorge, W., Unseld, M., Fartmann, B., Valle, G., Blocker, H., PerezAlonso, M., Obermaier, B. et al. 2000. Sequence and analysis of chromosome 3 of the plant Arabidopsis thaliana. Nature 408: 820-822.

Samach, A., Onouchi, H., Gold, S.E., Ditta, G.S., SchwarzSommer, Z., Yanofsky, M.F., and Coupland, G. 2000. Distinct roles of CONSTANS target genes in reproductive development of Arabidopsis. Science 288: 1613-1616.

Samach, A., and Gover, A. 2001. Photoperiodism: The consistent use of CONSTANS. Curr. Biol. 11: R651-654. Sanda, S.L., and Amasino, R.M. 1996. Interaction of FLC and late-flowering mutations in Arabidopsis thaliana. Mol. Gen. Genet. 251: 69-74.

Schaffer, R., Ramsay, N., Samach, A., Corden, S., Putterill, J., Carre, I.A., and Coupland, G. 1998. The late elongated hypocotyl mutation of Arabidopsis disrupts circadian rhythms and the photoperiodic control of flowering. Cell 93: 1219-1229.

Schaffer, R., Landgraf, J., Accerbi, M., Simon, V.V., Larson, M., and Wisman, E. 2001. Microarray analysis of diurnal and circadian-regulated genes in Arabidopsis. Plant Cell 13: 113-123.
Schomburg, F.M., Patton, D.A., Meinke, D.W., and Amasino, R.M. 2001. FPA, a gene involved in floral induction in Arabidopsis, encodes a protein containing RNA-recognition motifs. Plant Cell 13: 1427-1436.

Schultz, T.F., Kiyosue, T., Yanovsky, M.J., Wada, M., and Kay, S.A. 2001. A role for LKP2 in the circadian clock of Arabidopsis. Plant Cell 13: 2659-2670.

Scortecci, K.C., Michaels, S.D., and Amasino, R.M. 2001. Identification of a MADS-box gene, FLOWERING LOCUS $M$, that represses flowering. Plant J. 26: 229-236.

Sedgley, M., and Griffin, A.R. 1989. Sexual reproduction of tree crops. Academic Press, London.

Sharrock, R.A., and Quail, P.H. 1989. Novel phytochrome sequences in Arabidopsis thaliana: structure, evolution, and differential expression of a plant regulatory photoreceptor family. Genes Dev. 3: 1745-1757.

Sheldon, C.C., Burn, J.E., Perez, P.P., Metzger, J., Edwards, J.A., Peacock, W.J., and Dennis, E.S. 1999. The FLF MADS box gene: a repressor of flowering in Arabidopsis regulated by vernalization and methylation. Plant Cell 11: 445-458.

Silverstone, A.L., Ciampaglio, C.N., and Sun, T. 1998. The Arabidopsis $R G A$ gene encodes a transcriptional regulator repressing the gibberellin signal transduction pathway. Plant Cell 10: 155-169.

Simon, R., Igeño, M.I., and Coupland, G. 1996. Activation of floral meristem identity genes in Arabidopsis. Nature 384: 59-62.

Simpson, G.G., Gendall, A.R., and Dean, C. 1999. When to switch to flowering. Annu. Rev. Cell Dev. Biol. 15: 519550.

Somers, D.E., Schultz, T.F., Milnamow, M., and Kay, S.A. 2000. ZEITLUPE encodes a novel clock-associated PAS protein from Arabidopsis. Cell 101: 319-329.

Soppe, W.J., Jacobsen, S.E., Alonso-Blanco, C., Jackson, J.P., Kakutani, T., Koornneef, M., and Peeters, A.J. 2000. The late flowering phenotype of fwa mutants is caused by gain-of-function epigenetic alleles of a homeodomain gene. Mol. Cell 6: 791-802.

Strayer, C., Oyama, T., Schultz, T.F., Raman, R., Somers, D.E., Mas, P., Panda, S., Kreps, J.A., and Kay, S.A. 2000. Cloning of the Arabidopsis clock gene TOC1, an autoregulatory response regulator homolog. Science 289: 768-771.

Suárez-López, P., Wheatley, K., Robson, F., Onouchi, H., Valverde, F., and Coupland, G. 2001. CONSTANS mediates between the circadian clock and the control of flowering in Arabidopsis. Nature 410: 1116-1120.

Sugano, S., Andronis, C., Green, R.M., Wang, Z.Y., and Tobin, E.M. 1998. Protein kinase CK2 interacts with and phosphorylates the Arabidopsis circadian clockassociated 1 protein. Proc. Natl. Acad. Sci. U. S. A. 95: 11020-11025.

Sugano, S., Andronis, C., Ong, M.S., Green, R.M., and Tobin, E.M. 1999. The protein kinase CK2 is involved in regulation of circadian rhythms in Arabidopsis. Proc. Natl. Acad. Sci. U. S. A. 96: 12362-12366.

Sun, T.-p., and Kamiya, Y. 1994. The Arabidopsis GA1 locus encodes the cyclase ent-kaurene synthetase $A$ of gibberellin biosynthesis. Plant Cell 6: 1509-1518.

Sung, Z.R., Belachew, L., Shunong, B., and Bertrand- 
Garcia, R. 1992. EMF, an Arabidopsis gene required for vegetative shoot development. Science 258: 1645-1647. Szathmáry, E., Jordán, F., and Pál, C. 2001. Can genes explain biological complexity? Science 292: 1315-1316. Tabata, S., Kaneko, T., Nakamura, Y., Kotani, H., Kato, T., Asamizu, E., Miyajima, N., Sasamoto, S., Kimura, T., Hosouchi, T. et al. 2000. Sequence and analysis of chromosome 5 of the plant Arabidopsis thaliana. Nature 408: 823-826.

Tautz, D. 2000. Evolution of transcriptional regulation. Curr. Opin. Genet. Dev. 10: 575-579.

Tepperman, J.M., Zhu, T., Chang, H.S., Wang, X., and Quail, P.H. 2001. Multiple transcription-factor genes are early targets of phytochrome A signaling. Proc. Natl. Acad. Sci. U. S. A. 98: 9437-9442.

The C. elegans Sequencing Consortium. 1998. Genome sequence of the nematode $C$. elegans: a platform for investigating biology. Science 282: 2012-2018.

Theologis, A., Ecker, J.R., Palm, C.J., Federspiel, N.A., Kaul, S., White, O., Alonso, J., Altafi, H., Araujo, R., Bowman, C.L. et al. 2000. Sequence and analysis of chromosome 1 of the plant Arabidopsis thaliana. Nature 408: 816-820.

Venter, J.C., Adams, M.D., Myers, E.W., Li, P.W., Mural, R.J., Sutton, G.G., Smith, H.O., Yandell, M., Evans, C.A., Holt, R.A. et al. 2001. The sequence of the human genome. Science 291: 1304-1351.

Vision, T.J., Brown, D.G., and Tanksley, S.D. 2000. The origins of genomic duplications in Arabidopsis. Science 290: 2114-2117.

Wang, Z.Y., Kenigsbuch, D., Sun, L., Harel, E., Ong, M.S., and Tobin, E.M. 1997. A Myb-related transcription factor is involved in the phytochrome regulation of an Arabidopsis Lhcb gene. Plant Cell 9: 491-507.

Wang, Z.Y., and Tobin, E.M. 1998. Constitutive expression of the CIRCADIAN CLOCK ASSOCIATED 1 (CCA1) gene disrupts circadian rhythms and suppresses its own expression. Cell 93: 1207-1217.

Weigel, D., Alvarez, J., Smyth, D.R., Yanofsky, M.F., and Meyerowitz, E.M. 1992. LEAFY controls floral meristem identity in Arabidopsis. Cell 69: 843-859.

Weigel, D., Ahn, J.H., Blázquez, M.A., Borevitz, J.O., Christensen, S.K., Fankhauser, C., Ferrándiz, C., Kardailsky, I., Malancharuvil, E.J., Neff, M.M. et al. 2000. Activation tagging in Arabidopsis. Plant Physiol. 122: 1003-1013.

Wilson, R.N., Heckman, J.W., and Somerville, C.R. 1992. Gibberellin is required for flowering but not for senescence in Arabidopsis thaliana under short days. Plant Physiol. 100: 403-408.

Wright, F.A., Lemon, W., Zhao, W.D., Sears, R., Zhuo, D., Wang, J.-P., Yang, H.-Y., Baer, T., Stredney, D., Spitzner, J. et al. 2001. A draft annotation and overview of the human genome. Genome Biol. 2: research0025.00210025.0018.

Wu, K., Malik, K., Tian, L., Brown, D., and Miki, B. 2000. Functional analysis of a RPD3 histone deacetylase homologue in Arabidopsis thaliana. Plant Mol. Biol. 44: 167-176.

Yamaguchi, R., Nakamura, M., Mochizuki, N., Kay, S.A., and Nagatani, A. 1999. Light-dependent translocation of a phytochrome B-GFP fusion protein to the nucleus in transgenic Arabidopsis. J. Cell Biol. 145: 437-445.

Yang, C.H., Chen, L.J., and Sung, Z.R. 1995. Genetic regulation of shoot development in Arabidopsis: role of the EMF genes. Dev. Biol. 169: 421-435.

Yano, M., Katayose, Y., Ashikari, M., Yamanouchi, U., Monna, L., Fuse, T., Baba, T., Yamamoto, K., Umehara, Y., Nagamura, Y. et al. 2000. Hd1, a major photoperiod sensitivity quantitative trait locus in rice, is closely related to the Arabidopsis flowering time gene CONSTANS. Plant Cell 12: 2473-2484.

Yoshida, N., Yanai, Y., Chen, L., Kato, Y., Hiratsuka, J., Miwa, T., Sung, Z.R., and Takahashi, S. 2001. EMBRYONIC FLOWER2, a novel polycomb group protein homolog, mediates shoot development and flowering in Arabidopsis. Plant Cell. 13: 2471-2481.

Zagotta, M.T., Hicks, K.A., Jacobs, C.I., Young, J.C., Hangarter, R.P., and Meeks-Wagner, D.R. 1996. The Arabidopsis ELF3 gene regulates vegetative photomorphogenesis and the photoperiodic induction of flowering. Plant J. 10: 691-702.

Zhu, Y., Tepperman, J.M., Fairchild, C.D., and Quail, P.H. 2000. Phytochrome $B$ binds with greater apparent affinity than phytochrome $A$ to the basic helix-loop-helix factor PIF3 in a reaction requiring the PAS domain of PIF3. Proc. Natl. Acad. Sci. U. S. A. 97: 13419-13424. 


\section{Further Reading}

Caister Academic Press is a leading academic publisher of advanced texts in microbiology, molecular biology and medical research. Full details of all our publications at caister.com

- MALDI-TOF Mass Spectrometry in Microbiology Edited by: M Kostrzewa, S Schubert (2016) www.caister.com/malditof

- Aspergillus and Penicillium in the Post-genomic Era Edited by: RP Vries, IB Gelber, MR Andersen (2016) www.caister.com/aspergillus2

- The Bacteriocins: Current Knowledge and Future Prospects Edited by: RL Dorit, SM Roy, MA Riley (2016)

www.caister.com/bacteriocins

- Omics in Plant Disease Resistance Edited by: V Bhadauria (2016) www.caister.com/opd

- Acidophiles: Life in Extremely Acidic Environments Edited by: R Quatrini, DB Johnson (2016) www.caister.com/acidophiles

- Climate Change and Microbial Ecology: Current Research and Future Trend

Edited by: J Marxsen (2016)

www.caister.com/climate

- Biofilms in Bioremediation: Current Research and Emerging Technologies

Edited by: G Lear (2016)

www.caister.com/biorem

- Microalgae: Current Research and Applications Edited by: MN Tsaloglou (2016) www.caister.com/microalgae

- Gas Plasma Sterilization in Microbiology: Theory, Applications, Pitfalls and New Perspectives Edited by: H Shintani, A Sakudo (2016) www.caister.com/gasplasma

- Virus Evolution: Current Research and Future Directions Edited by: SC Weaver, M Denison, M Roossinck, et al. (2016) www.caister.com/virusevol

- Arboviruses: Molecular Biology, Evolution and Control Edited by: N Vasilakis, DJ Gubler (2016) www.caister.com/arbo

- Shigella: Molecular and Cellular Biology Edited by: WD Picking, WL Picking (2016) www.caister.com/shigella

-Aquatic Biofilms: Ecology, Water Quality and Wastewater Treatment

Edited by: AM Romaní, H Guasch, MD Balaguer (2016)

www.caister.com/aquaticbiofilms

- Alphaviruses: Current Biology

Edited by: S Mahalingam, L Herrero, B Herring (2016)

www.caister.com/alpha

- Thermophilic Microorganisms

Edited by: F Li (2015)

www.caister.com/thermophile
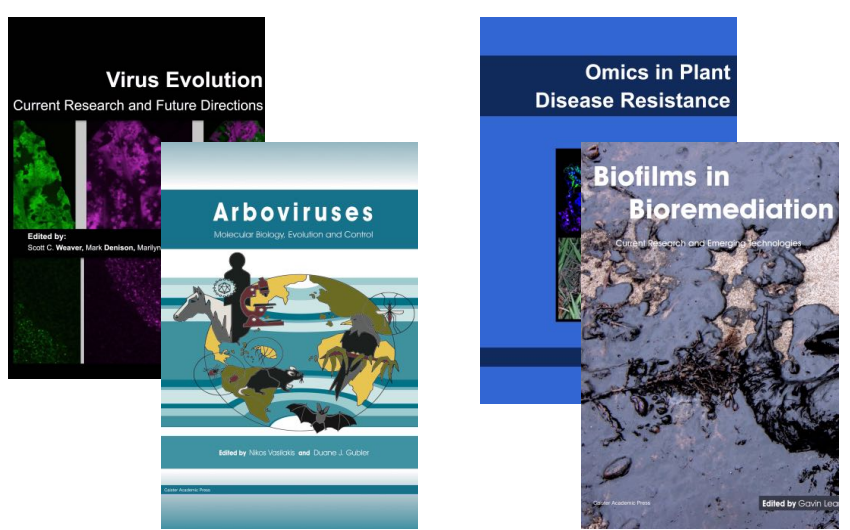


- Flow Cytometry in Microbiology: Technology and Applications Edited by: MG Wilkinson (2015) www.caister.com/flow

- Probiotics and Prebiotics: Current Research and Future Trends Edited by: K Venema, AP Carmo (2015) www.caister.com/probiotics

- Epigenetics: Current Research and Emerging Trends Edited by: BP Chadwick (2015) www.caister.com/epigenetics2015

- Corynebacterium glutamicum: From Systems Biology to Biotechnological Applications

Edited by: A Burkovski (2015)

www.caister.com/cory2

- Advanced Vaccine Research Methods for the Decade of Vaccines

Edited by: F Bagnoli, R Rappuoli (2015)

www.caister.com/vaccines

- Antifungals: From Genomics to Resistance and the Development of Novel Agents

Edited by: AT Coste, P Vandeputte (2015)

www.caister.com/antifungals

- Bacteria-Plant Interactions: Advanced Research and Future Trends Edited by: J Murillo, BA Vinatzer, RW Jackson, et al. (2015) www.caister.com/bacteria-plant

\section{- Aeromonas}

Edited by: J Graf (2015)

www.caister.com/aeromonas

- Antibiotics: Current Innovations and Future Trends

Edited by: S Sánchez, AL Demain (2015)

www.caister.com/antibiotics

- Leishmania: Current Biology and Contro Edited by: S Adak, R Datta (2015) www.caister.com/leish2

- Acanthamoeba: Biology and Pathogenesis (2nd edition) Author: NA Khan (2015)

www.caister.com/acanthamoeba2

- Microarrays: Current Technology, Innovations and Applications Edited by: Z He (2014)

www.caister.com/microarrays2

- Metagenomics of the Microbial Nitrogen Cycle: Theory, Methods and Applications

Edited by: D Marco (2014)

www.caister.com/n2 